\title{
The proteases, amylase and lipase of the pancreas and intestinal contents of germ-free and conventional rats
}

\author{
By S. LEPKOVSKY, F. FURUTA, K. OZONE AND T. KOIKE \\ Department of Poultry Husbandry, University of California, \\ Berkeley, California, USA \\ AND M. WAGNER \\ Department of Biology, Lobund Institute, University of Notre Dame, \\ Notre Dame, Indiana, USA \\ (Received 6 August 1965-Accepted 3 October 1965)
}

\begin{abstract}
I. Measurements were made of the proteases, amylase and lipase of the pancreas and of the corresponding intestinal, caecal and colonic contents of germ-free and conventional rats. 2. Little difference was found between the concentration of the enzymes in the germ-free and conventional rats. 3. The results indicate that intestinal bacteria had only a minor part in determining the fate of the pancreatic enzymes in the contents of the intestine, caecum and colon. 4. The enzyme concentrations decreased caudally. The proteases were the most stable, and the amylase was the least stable; the stability of lipase was intermediate between that of the proteases and amylase. 5. Evidence of bacterial activity in the caecal contents of conventional rats was seen in the greater percentage of protein nitrogen and in the lower percentage of the non-protein nitrogen.
\end{abstract}

In earlier studies of pancreatic function in rats, measurements were made of the activities of the proteases, amylase and lipase of the pancreas and of the contents of the intestine, caecum and colon (Lepkovsky, unpublished). It was difficult to interpret the values obtained for the contents of the intestine, caecum and colon because the measurements represented the sum of the activity of enzymes entering the duodenum with the pancreatic juice, of the losses due to inactivating mechanisms in the intestinal lumen and of the losses or gains due to the activity of the microflora. Information was needed about the changes brought about by the action of the microflora upon the activities of the proteases, amylase and lipase in the intestinal contents. Accordingly, the activities of these enzymes were measured in the contents of the intestine, caecum and colon of the germ-free and conventional rat.

\section{EXPERIMENTAL}

Animals and treatment. Female rats of the Lobund germ-free rat colony (twelfth generation) were reared in a Reyniers-type germ-free isolator (Reyniers, Trexler \& Ervin, 1946; Reyniers, 1959). Conventional female rats of the same strain (originally derived from Wistar stock) were reared in open wire-mesh cages in the conventional animal house. All rats were fed on the autoclaved L-356 diet (Larner \& Gillespie, 1957) with water $a d l i b$. to the age of 127 days. Eight germ-free and seven conventional rats were then anaesthetized and killed by exsanguination through a cardiac puncture. 
Collection of the pancreases and intestinal contents from germ-free and conventional rats. Germ-free rats were removed one at a time from the germ-free isolator and killed immediately; the small intestines were divided into three equal parts. Contents from each part and from the caecum, the colon and the faeces were all collected separately in previously sterilized screw-cap vials. The faeces were pellets voided during anaesthesia and exsanguination and may be considered as lower colon contents since the undisturbed animal would probably have retained this material for a longer period of time. The pancreases were also stored in separate screw-capped vials. All specimens were quick-frozen with dry ice immediately after collection from each animal and stored at $-25^{\circ}$. The conventional rats were killed and the intestinal contents and pancreases were treated in the same manner. The frozen specimens were refrigerated with dry ice and shipped by air express from Lobund to the University of California for enzyme analysis; upon arrival the frozen samples were freeze-dried.

Analytical procedures. Trypsinogen in the pancreas was activated (Kunitz, 1938-9) as follows: $2 \mathrm{ml}$ of sample, $\mathrm{I} \cdot 0 \mathrm{ml} \mathrm{O} \cdot \mathrm{I} \mathrm{M}$-phosphate buffer $\mathrm{pH} 5.6$, and $2.0 \mathrm{ml}$ enterokinase solution ( $0.5 \%$ duodenum powder; VioBin Corporation, Monticello, Ill.) were incubated for $30 \mathrm{~min}$ at $37^{\circ}$. The reaction was stopped by the addition of $5.0 \mathrm{ml}$ $0.04 \mathrm{~N}-\mathrm{HCl}$. To $0.5 \mathrm{ml}$ of this mixture was added $0.5 \mathrm{ml}$ of a $0.5 \%(\mathrm{w} / \mathrm{v})$ aqueous solution of $\mathrm{CaCl}_{2}$ and, after incubation with haemoglobin substrate, the proteases were determined by the method of Anson (1938-9).

The 'trypsin' fraction of the proteases was determined as follows: $0.2 \mathrm{mg}$ of a soyabean trypsin inhibitor (Worthington Biochemical Corporation, Freehold, New Jersey) was added to the sample and the residual protease activity was determined. The difference is reported as the percentage of 'trypsin'.

Amylase was determined using a substrate prepared by the method of McCready \& Hassid (1943); the incubation was carried out by the method of Smith \& Roe (1949). The starch-iodide colour was read in a spectrophotometer (Beckman, Model B) at a wave-length of $650 \mathrm{~nm}$ after setting the instrument at $100 \%$ transmittance with distilled water.

Lipase activity was estimated by incubating the sample with Ediol (coconut oil emulsion; Schenley Laboratory, Inc., Lawrenceburg, Indiana) as the substrate using the method of Balls, Matlack \& Tucker (1937-8), and the fatty acids released were determined by the Dole (1956) procedure. The incubation mixture consisted of Ediol ( $50 \%$ coconut oil emulsion), $0.1 \mathrm{ml} ; 5 \%$ aqueous solution of sodium taurocholate, $0.5 \mathrm{ml} ; 0.1 \mathrm{M}-\mathrm{CaCl}_{2}, 0.5 \mathrm{ml} ; 0.6 \mathrm{M}-\mathrm{NH}_{4} \mathrm{Cl}_{-}-\mathrm{NH}_{3}$ buffer $(\mathrm{pH} \mathrm{8.5)}, 0.3 \mathrm{ml}$; water, $0.1 \mathrm{ml}$; sample, $0.5 \mathrm{ml}$. The total volume was $2.0 \mathrm{ml}$. To I $\mathrm{ml}$ were added $5.0 \mathrm{ml}$ of the extraction mixture (2-propanol, 4 \% parts; heptane, Io parts; $\mathrm{N}-\mathrm{H}_{2} \mathrm{SO}_{4}$, I part) to prevent lipase action, and this portion served as the control. The remaining I $\mathrm{ml}$ was incubated at $37^{\circ}$ for $20 \mathrm{~min}$, after which the extraction mixture was added (Dole, 1956).

Whenever sufficient material was available, protein and non-protein nitrogen were determined in the samples as follows. A homogenate containing about $20 \mathrm{mg}$ of dry intestinal contents per $\mathrm{ml}$ was prepared. Total nitrogen was determined on the whole 
homogenate by the standard micro-Kjeldahl method. One volume of $20 \%(\mathrm{w} / \mathrm{v})$ trichloroacetic acid (TCA) solution was mixed with I volume of homogenate; the mixture was allowed to stand for $\mathrm{I} h$ and was then centrifuged. Nitrogen was determined in the TCA filtrate. The protein nitrogen was calculated by subtracting the value for non-protein nitrogen (nitrogen of the TCA filtrate) from that for total nitrogen (nitrogen of the whole homogenate). All values reported are based upon the dry weight.

The results are shown in Table $\mathrm{I}$.

$$
\text { RESULTS }
$$

\section{Pancreas}

There were no differences in activities of the proteases, amylase and lipase of the pancreas between the germ-free and the conventional rats.

Table I. Nitrogen content and proteases, amylase and lipase activities of the pancreas and of the intestinal, caecal and colon contents of germ-free and conventional rats

(Mean values and standard deviations for eight germ-free or seven conventional rats)

\begin{tabular}{|c|c|c|c|c|c|c|c|c|c|c|}
\hline \multirow[b]{3}{*}{ Type of rat } & \multicolumn{10}{|c|}{ Enzyme activity* } \\
\hline & \multicolumn{2}{|c|}{$\begin{array}{c}\text { Nitrogent } \\
(\%)\end{array}$} & \multicolumn{2}{|c|}{ Proteasef } & \multicolumn{2}{|c|}{ Amylase§ } & \multicolumn{2}{|c|}{ Lipase\| } & \multicolumn{2}{|c|}{ 'Trypsin' } \\
\hline & Mean & $\mathrm{SD}$ & Mean & SD & Mean & SD & Mean & SD & Mean & SD \\
\hline \multicolumn{11}{|c|}{ Pancreas } \\
\hline Germ-free & $8 \cdot 5$ & I.O & $6 \cdot 21$ & $2 \cdot 52$ & $630 \cdot 0$ & 122 & $257 \cdot 0$ & 70 & $78 \cdot 0$ & $1 \cdot 4$ \\
\hline Conventional & $8 \cdot 2$ & $1 \cdot 2$ & $4 \cdot 76$ & $\mathrm{I} \cdot 38$ & $567 \cdot 0$ & 48 & $259 \cdot 0$ & 89 & $79 \cdot 6$ & $2 \cdot 6$ \\
\hline \multicolumn{11}{|c|}{ Intestinal contents - upper one-third } \\
\hline Germ-free & 10.6 & $I \cdot 6$ & 0.75 & 0.28 & $79^{\circ} \circ$ & 26 & II $\cdot 2$ & $4^{*} I$ & $74 \cdot 3$ & $4 \%$ \\
\hline Conventional & $10 \cdot 5$ & 0.7 & 0.92 & 0.21 & $\operatorname{II} 3 \cdot 0$ & 40 & $17 \cdot 3$ & $4 \cdot 5$ & 73.9 & $3 \cdot 0$ \\
\hline \multicolumn{11}{|c|}{ Intestinal contents - middle one-third } \\
\hline Germ-free & $7 \cdot 3$ & $\mathrm{I} \cdot 6$ & $I \cdot 79$ & 0.54 & $119 \cdot 0$ & 20 & $14 \cdot 6$ & $3 \cdot 9$ & $78 \cdot 3$ & $5 \cdot 5$ \\
\hline Convent & $7 \cdot 4$ & 0.6 & $I \cdot 96$ & 0.60 & I 13.0 & 69 & $17 \cdot 3$ & $3 \cdot I$ & $74 \cdot 8$ & $3 \cdot 1$ \\
\hline \multicolumn{11}{|c|}{ Intestinal contents-lower one-third } \\
\hline Germ-free & $4 \cdot 1$ & $I \cdot O$ & $I \cdot 50$ & 0.28 & $16 \cdot 0$ & $4 \cdot 0$ & $8 \cdot 7$ & 4.7 & $78 \cdot 5$ & $\mathrm{I} \cdot 4$ \\
\hline Conventional & $5^{\prime} I$ & 0.6 & $1 \cdot 22$ & 0.26 & I I $2 \cdot 0$ & 45.0 & $9 \cdot 2$ & $2 \cdot 5$ & $74 \cdot 4$ & $4: 3$ \\
\hline \multicolumn{11}{|c|}{ Caecal contents } \\
\hline Germ-free & $5 \cdot 2$ & 0.4 & $I \cdot 15$ & 0.20 & $2 \cdot 2$ & 0.3 & $5 \cdot 1$ & I.O & 80.9 & $2 \cdot 5$ \\
\hline Conventional & 4.4 & 0.4 & 0.77 & 0.27 & $9 \cdot 7$ & 4.7 & 577 & I.9 & $76 \cdot 1$ & $2 \cdot 4$ \\
\hline \multicolumn{11}{|c|}{ Colon contents } \\
\hline Germ-free & $4 \cdot 3$ & 0.3 & 0.93 & 0.27 & $I \cdot 6$ & 0.3 & $6 \cdot 2$ & $I \cdot 5$ & $78 \cdot 9$ & $3 \cdot 8$ \\
\hline Conventional & $3 \cdot 9$ & 0.2 & 0.82 & $0.1 \mathrm{I}$ & $6 \cdot 7$ & $2 \cdot 6$ & $4 \cdot 3$ & $2 \cdot 1$ & $77 \cdot 3$ & $4 \cdot 2$ \\
\hline \multicolumn{11}{|c|}{ Colon contents-'faeces' voided during anaesthesia } \\
\hline 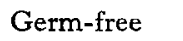 & $3 \cdot 6$ & 0.2 & 0.78 & 0.26 & $\mathbf{I} \cdot \mathbf{I}$ & 0.1 & $5 \cdot 7$ & 0.7 & $76 \cdot 8$ & $2 \cdot 0$ \\
\hline Conventional & $3 \cdot 8$ & 0.5 & 0.54 & 0.15 & $3 \cdot 6$ & 3.2 & $4 \cdot 7$ & $1 \cdot 3$ & $73 \cdot 5$ & $2 \cdot 6$ \\
\hline
\end{tabular}

* All enzymes incubated at $37^{\circ}$ and all enzyme activities except 'trypsin' expressed as per $\mathrm{g}$ dry solids.

$\uparrow$ Expressed on a dry-matter basis.

Expressed as m-equiv. tyrosine released in $10 \mathrm{~min}$.

$\S$ Expressed as $\mathrm{mg}$ starch digested in $15 \mathrm{~min} \times 10^{-3}$.

II Expressed as m-equiv. fatty acids released in $20 \mathrm{~min}$. 


\section{Intestinal contents}

Nitrogen. There was little difference between the germ-free and conventional rats in the percentage of nitrogen in the contents of the small intestine, caecum and colon. In both kinds of animal the percentage was highest in the contents of the upper onethird of the small intestine and decreased in the middle one-third of the small intestine, with little further change in the contents of the caecum and colon.

Proteases. There was little difference between germ-free and conventional rats in the proteolytic activity of the contents of the small intestine, caecum and colon. In both kinds of animal proteolytic activity was highest in the contents of the middle one-third of the intestine and decreased a little in the lower one-third. Somewhat lower values were found in the contents of the upper one-third of the small intestine, caecum and colon.

\section{Table 2. Percentages of protein and non-protein nitrogen in caecal contents of germ-free and conventional rats}

(Values for individual rats)

\begin{tabular}{ccc}
\multicolumn{3}{c}{ Germ-free } \\
$\overbrace{\text { Total }}^{\text {Non-protein }}$ & $\begin{array}{c}\text { Protein } \\
\text { N }\end{array}$ \\
5.3 & N & \\
5.9 & 3.3 & 2.0 \\
5.4 & 4.7 & 1.2 \\
5.3 & 4.9 & 0.5 \\
& 4.4 & 0.7
\end{tabular}

$\begin{array}{ccl}\text { Total } & \text { Conventional } & \\ \mathrm{N} & \mathrm{Non-protein} & \begin{array}{c}\text { Protein } \\ \mathrm{N}\end{array} \\ 3.45 & \mathrm{I} \cdot 7 & 1 \cdot 75 \\ 4.25 & 2 \cdot \mathrm{I} & 2 \cdot 15 \\ 4.70 & 2 \cdot 3 & 2 \cdot 4 \\ 4.25 & 2 \cdot 0 & 2 \cdot 25\end{array}$

Amylase. The amylase activity of the contents of the upper and middle thirds of the small intestine was much the same in the germ-free and conventional rats. The amylase activity of the contents of the lower one-third of the small intestine of germfree rats was markedly below that of the middle third; with the conventional rats there was no such difference. Amylase activity was lower in the contents of the caecum and colon in both kinds of animal but the difference was more pronounced in the germfree ones.

Lipase. Lipase activity was much the same in the germ-free and conventional rats in the small intestine, caecum and colon. There was a moderate progressive decrease in lipase activity of the contents of the intestine of both kinds of animal as this material moved from the upper and middle thirds of the small intestine to the lower third of the intestine, caecum and colon.

Trypsin. There was no difference in the trypsin fraction in the contents of the small intestine, caecum and colon of germ-free and conventional rats.

Distribution of nitrogen in caecal contents. Although there was little difference in the percentage of nitrogen in the contents of the caecums of germ-free and conventional rats (Table $I$ ), the distribution of the protein nitrogen and non-protein nitrogen was different; the percentage of protein nitrogen was lower in germ-free rats than in conventional rats, and the percentage of non-protein nitrogen was higher (Table 2). 


\section{DISCUSSION}

The evidence indicated that the intestinal bacteria played only a small part in determining the fate of the pancreatic enzymes in the intestinal contents of the rats. Rather, this study points to other mechanisms that largely determined the fate of these enzymes, and the fate of each was different. The proteases in the intestinal contents of both germ-free and conventional rats were the most stable, since there were comparatively small decreases in these enzymes as they moved with the intestinal contents from the small intestine to the caecum and colon. By contrast, little of the amylase activity in the contents of the small intestine reached the caecum and colon. The stability of lipase was intermediate between that of the proteases and amylase.

Luckey (1964) showed that although there is an abundance of bacteria in the caecums of conventional rats, the gross chemical compositions of the excreta of germ-free and conventional rats are very similar. In our study, there was little difference between germ-free and conventional rats in the percentage of nitrogen in the caecal contents (Table I), but larger differences were seen in the percentage of protein and nonprotein nitrogen; non-protein nitrogen was higher in the caecal contents of germ-free rats and protein nitrogen was higher in conventional rats (Table 2).

This investigation was supported in part by Public Health Service Research Grants A-1804 and A-1805 from the National Institutes of Health and Grant GB-242 from the National Science Foundation, and in part by the Office of Naval Research and the Army Surgeon General (Contract NONR-1623-04), by Grant A-566 (c8) from the National Institutes of Health, and by the University of Notre Dame.

\section{REFERENCES}

Anson, M. L. (1938-9). F. gen. Physiol. 22, 79.

Balls, A. K., Matlack, M. B. \& Tucker, I. W. (1937-8). $\%$. biol. Chem. I22, 25.

Dole, V. P. (1956). F. clin. Invest. 35, I 50.

Kunitz, M. (1938-9). F. gen. Physiol. 22, 429.

Larner, J. \& Gillespie, R. E. (1957). F. biol. Chem. 225, 279.

Luckey, T. D. (1964). In Conference on Nutrition in Space and Related Waste Problems, University of South Florida, Tampa, Fla., p, 227. Washington, DC: National Aeronautics and Space Administration.

McCready, R. M. \& Hassid, W. Z. (1943). F. Am. chem. Soc. 65, 1154.

Reyniers, J. A. (1959). Ann. N.Y. Acad. Sci. 78, 47.

Reyniers, J. A., Trexler, P. C. \& Ervin, R. F. (1946). Lobund Rep. no. I.

Smith, B. W. \& Roe, J. H. (1949). F. biol. Chem. 179, 53. 